\title{
Decision Support System Development to Groundwater Management and Aquifer Vulnerability Assessment: Hydrogeological Information System of Monastir (HISM)
}

\author{
Imen Hentati ${ }^{1,2}$, Mohamed Ali Fourati ${ }^{3}$, Nadia Trabelsi ${ }^{1}$, Ibtissem Triki ${ }^{1,2}$, Saïd Sassi ${ }^{4}$, \\ Moncef Zairi ${ }^{1}$
}

\author{
${ }^{1}$ Laboratoire Eau, Energie, Environnement, Ecole Nationale d'Ingénieurs de Sfax, Sfax, Tunisia \\ ${ }^{2}$ Faculté des Sciences de Gafsa, Campus universitaire, Gafsa, Tunisia \\ ${ }^{3}$ Ecole Nationale d'Ingénieurs de Sfax, Sfax, Tunisia \\ ${ }^{4} \mathrm{STE}$ ooDiRoo, Ejjwabeur Kerkenah, Sfax, Tunisia \\ Email: ‘imenhentati@yahoo.fr, mohamed-ali.fourati@enis.tn, nadysonia@yahoo.fr, triki_ibtissem@yahoo.fr, sassi_said@live.fr, \\ moncef.zairi@enis.rnu.tn
}

How to cite this paper: Hentati, I., Fourati, M.A., Trabelsi, N., Triki, I., Sassi, S. and Zairi, M. (2019) Decision Support System Development to Groundwater Management and Aquifer Vulnerability Assessment: Hydrogeological Information System of Monastir (HISM). Journal of Geographic Information System, 11, 522-540. https://doi.org/10.4236/igis.2019.115032

Received: July 26, 2019

Accepted: October 8, 2019

Published: October 11, 2019

Copyright $\odot 2019$ by author(s) and Scientific Research Publishing Inc. This work is licensed under the Creative Commons Attribution International License (CC BY 4.0).

http://creativecommons.org/licenses/by/4.0/

(c) (7) Open Access

\begin{abstract}
In Tunisia and particularly in Monastir region, groundwater constitutes the main source of water supply systems. A lot of problems are facing the water management authorities. In fact, the Moknine coastal aquifer highlights several qualitative and quantitative anomalies due to the irrigated perimeters extension (Teboulba, Bekalta), releases of harmful products from the textile industry (Ksar Hellal and Moknine), intense overexploitation and seawater intrusion. Thus, for groundwater resources management, a Decision Support System (DSS) is developed for the Monastir region. This Decision Support System (DSS) brings together, on a digital support, the data descriptive and graphical component for groundwater management. It is a hydrogeological relational database joined with a Hydrogeological Information System for the Monastir region (HISM) which enables fast and effective processing of large volumes of spatial data from multiple sources. The implementation of the Hydrogeological Information System is assured using Object-Oriented Programming (OOP). The "Unified Modeling Language" (UML) is an Object-Oriented Design (OOD) methodology which is choiced for data modeling. The application interfaces have been developed in Visual Basic (VB.net) within the Integrated Development Environment (IDE) from Microsoft Visual Studio. "DotSpatial" library integrated is used to manage the geographic information layers. The HISM contains thematic layers acquired through the vectorization of 22 topographic and geologic maps $(1 / 50,000$ and $1 / 25,000)$
\end{abstract}


and the input of descriptive data from water well and pollution sources from field and laboratory studies. The HISM has a great management capacity; it ensures the conversion from the geographic coordinates to the planimetric coordinates. It allows adding, modifying, deleting and editing data (Rainfall, piezometric and geochemical). It also ensures the storage and editing of the digitized and/or generated cartographic database. This DSS was applied to the superficial coastal aquifer system of Moknine to define a conceptual model of groundwater functioning and assessment vulnerability to seawater intrusion.

\section{Keywords}

HISM, UML, DSS, DotSpatial, Vulnerability

\section{Introduction}

The Monastir region, characterized by water scarcity, is experiencing a significant demographic and industrial growth. The problem of groundwater degradation is exacerbated by the climatic conditions and water requirements for different anthropogenic activities and by pollution sources [1]. This degradation is generally expressed by the groundwater level depletion and the decline in the quality of these waters. Reliability and validity of groundwater analysis strongly depend on the availability of large volumes of high-quality data. Putting all data into a coherent and logical structure supported by a computing environment helps to ensure validity and availability and provides a powerful tool for hydrogeological studies [2].

In this situation, a DSS for the management and the planning of these resources seems essential. As a matter of fact, the Geographic Information Systems (GIS) offer modern tools to create maps, integrate information, visualize scenarios, solve complex problems and implement effective solutions based on the data collected from various sources and different formats [3] [4] [5]. State-of-the-art studies had disclosed the higher impact of applying GIS systems on groundwater analysis and hydrogeological decision support. Many studies [6] [7] had contributed to the development of approaches and methods integrated within geographical information systems in order to help users to understand current states of groundwater resources in their regions. In such projects [8] [9] [10] [11], GIS systems had been deployed to improve the management of groundwater resources supply and urban allocation. On the other side, geographic GIS systems are just deployed as geodatabases [12]. In this paper, we propose to develop a GIS system that integrates at the same time already mentioned features (database and spatial analysis approach).

From a technical perspective, the design of most information system is based on the MERISE approach [13] [14] [15]. In our study, the design and implementation of the DSS are based on Object-Oriented approach. The object approach combines the data and treatments ensuring, thus a certain level of cohe- 
rence. Indeed, the UML approach allows model complex systems and express in a way integrated the structure and dynamics with the same concept more close to the reality of things.

In this context, the objectives were: 1) to develop a hydrogeological database linked to an Information System enabling the storing, editing, and displaying of the geographic referenced data, 2) to process and analyze the spatially distributed data, 3) to properly support aquifer-vulnerability assessments, and 4) to introduce a conceptual model of groundwater functioning. A GIS-managed hydrogeological database has been developed in order to provide data used in vulnerability assessment techniques and analyses.

The paper is structured as follows. This introductory section is followed by a general overview of GIS and object approach. The third section offers a detailed description of the methodology employed from design to software implementation and development. The application of the DSS to the superficial coastal aquifer of Moknine is discussed in the fourth section. The main conclusions are underlined in the last section.

\section{A General Overview of GIS and Object Approach}

\subsection{GIS Systems}

GIS is now well recognized as a science and can be considered as a relatively new and emerging area [16]. It is defined as a system for input, storage, manipulation, and output of geographically referenced data [17]. The GIS technology is used for managing spatial and non-spatial data, linking models, and providing interfaces between the models and their users [18].

Geographic data can be represented by GIS systems as either objects or fields. The objects represent entities are characterized by geometry, topology, and non-spatial attribute values. The fields represent the real data attributes and components [19]. In fact, this distinction between objects and fields in GIS is often associated with vector and raster data models. On one hand, the vector models represent spatial phenomena through differences in the distribution of properties of points, lines, and areas. In such system, each layer is an adapted combination of one or more classes of geometrical features. On the other hand, a raster model consists of a rectangular array of cells with values being assigned to each cell. In such model, each cell is usually restricted to a single value. Consequently, the spatial representation of distributed parameters and variables requires an architecture based on multiple layers and relationship models where different data needs to be well manipulated, analyzed and combined [2] [20].

\subsection{Object-Oriented Development}

Object-oriented development is a methodology that syntheses approach of both conceptual modeling and object-oriented programming [21]. Object-Oriented Analysis (OOA) addresses conceptual expressions of real-world processes or systems within the object-oriented paradigm [22]. Object-Oriented Design 
(OOD) can be used to decompose a problem into manageable parts and depict logical aspects of a system using consistent notations [23].

These methodologies are based on the concepts of objects and classes with relations of abstraction, encapsulation and inheritance which are powerful features of object orientation. Encapsulation is a mechanism for improving the flexibility and comprehensibility of a system allowing the development time saving, the integrity of the analyzed data and the correct writing of services [21] [24]. Polymorphism allows different instantiations of objects where each one can be presented in an appropriate way according to the others which allow the system extension [25]. Inheritance is a mechanism by which a class (subclass) refines the behavior and properties of some other class [21].

All these concepts can be performed using Unified Modeling Language (UML). In fact, researchers have adopted the UML as graphical notation to support object-oriented modeling and application development [25]. UML can be used to develop conceptual models of processes and facilitate implementation of databases and systems depending on the computational environment [25]. UML is a modeling language using text and graphical notations that assures specification, analysis, design and implementation of object-oriented system development process. It can be used with all processes throughout the development life cycle and across different implementation technologies [21]. Each object is identified using a unique value known as an object identifier (OID). This unique identifier enables an object to distinguish itself from other objects when such behavior is specified [23]. Similar objects are grouped into classes. A class can be defined as a collection of physical or logical things uniformly described using the same attributes, operations, relationships, and semantics [26]. Classes are the primary organizational unit of object-oriented systems, providing a means for describing the structure and behavior of individual system objects [25]. Classes define properties and behavior of sets of objects. An attribute represents some property of the class [21]. Behavior of objects is realized via operations. An operation is a function or transformation that may be applied on objects in a class. The execution of a method may change the state of an object [21]. A method is an abstraction of something that an object can do, or have done to it [27]. Relationships provide a pathway for communication between objects [28]. There are connections between things and appear on UML class diagrams as lines connecting classes [22]. Generalization and associations are the most frequently occurring type of relationship. The application of generalization enables description of systems and processes using a hierarchy of classes [29]. Associations represent static relationships between classes.

\section{Methodological Approach}

A practical methodology in this study is presented as flowchart in Figure 1 [30]. The first phase involves searching for, retrieving and collecting data related to the study area. This is the longest and most expensive phase [31]. In the second 


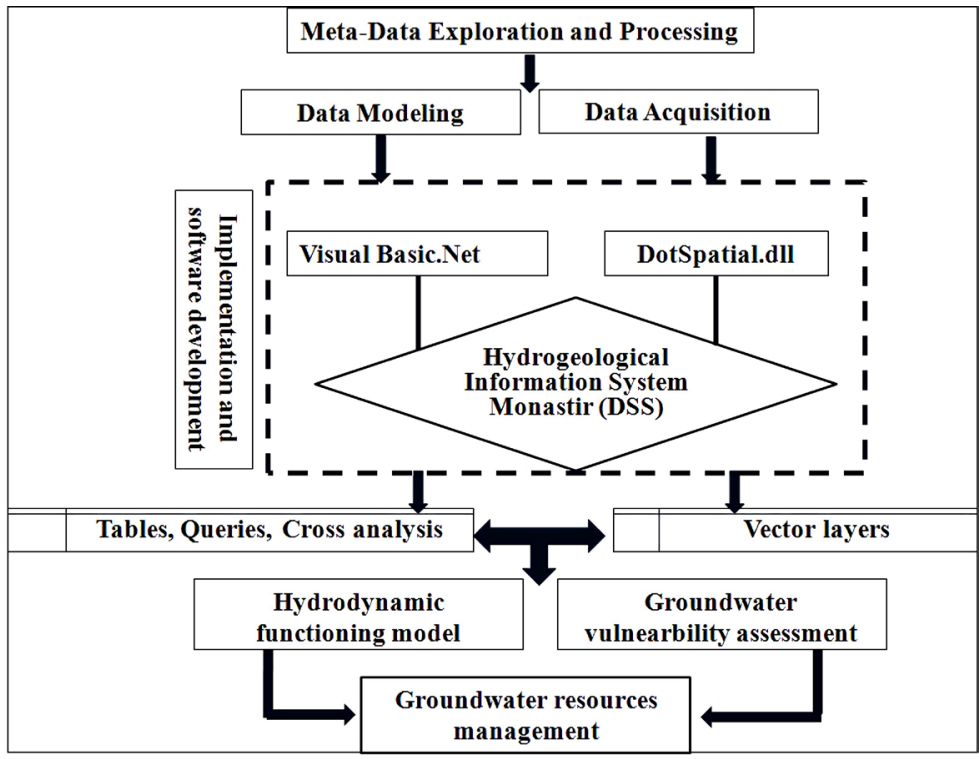

Figure 1. Flowchart of methodology for data acquisition and processing [30].

phase, the collected data should be modeling and introduced in digital form. The DSS is developed in Visual Basic (VB.net) using the Visual Studio Integrated Development Environment (IDE) with the geographic information system library "DotSpatial". The reporting techniques as vector layers, cross analysis and queries were exploited and combined to develop new thematic and representative maps in order to introduce a conceptual model of groundwater functioning and study their vulnerabilities to pollution.

\subsection{Meta-Data Exploration and Processing}

The purpose of developing the hydrogeological database was to store the main data and integrate useful information by the hydrogeologist. Data are collected from existing databases and maps as well as through new field measurements. The sources of information can be of various origins. The necessary data (topographic, hydrographic, geologic, soil, piezometric ...) are gathered from three different sources:

- Field surveys for the inventory and exploration of the region;

- Consultation of old research and historical data on the region;

- The vectorization of the different existing maps.

Existing and required data types were examined in order to design the database scheme. Parameters and information were reclassified and regrouped at several times. Many hydrogeological parameters and relationships were analyzed in order to be stored in the database. Maximum information, minimum data redundancy, reduction of storage capacity, and optimum retrievability of data for analysis were the constraints that defined the final scheme [2]. This data management tool allows updating and checking of data in real time, automating data storage, management procedures as well as time-series analysis and the production of detailed hydrogeological maps [28]. 


\subsection{Data Modeling}

The conceptual design of database is a process to abstract the user needs to information model [32]. The cartographic modeling is the first step in the geographical information system realization. This function is used to model the real data according to the needs and the desired objectives. Table 1 illustrates the mapping model of the objects for the DSS. Topography is represented by contour lines. Point information describes the groundwater and rainfall layers. The groundwater level measurement, hydrochemistry and permeability layers derived from processed attributes data.

The system design is a creative and an essential phase in the development process. Applying of conceptual modeling aims at considering more adequate requirements in the development of the Information Systems according to their operating environments.

For the DSS conceptual modeling, we chose the UML. In fact, it provides a standard way to visualize a design using diagrams. UML includes a set of graphic notation techniques to create visual models of software-intensive systems [26]. There are two major kinds of UML diagram: static and dynamic diagrams. For the static diagrams, we present the use-case and classes diagrams. For the dynamic diagrams, we present the sequence diagrams.

\subsubsection{Use-Case Diagram}

The use-case diagram describes a set of actions that the DSS should perform in collaboration with the users (actors) of the system to provide valuable results. Figure 2 illustrates the use-case diagram which is a basic element of object-oriented modeling. The functionality of the system is determined by examining the needs of each actor that will be stated as an interaction family. Moreover, the user of the application will implement the data (water well, sample, analysis, rainfall stations, water tables and maps), select the appropriate parameter,

Table 1. Layers of hydrogeological database.

\begin{tabular}{ccc}
\hline Object & Topology & Layer \\
\hline Contour lines & Arc & Topography \\
Geological formations & Polygon & Geology \\
Surface-water & Polygon & Surface-water bodies \\
Street network & Arc & Transportation \\
Hydrographic network & Arc & Hydrography \\
Cities & Point & Place names \\
Climatic measurement stations & Point & Rain water \\
Wells, piezometers & Point & Groundwater \\
Permeability of a layer & Polygon/Arc & Permeability \\
Hydraulic headl piezometric head & Arcl Point & Groundwater Level Measurement
\end{tabular}




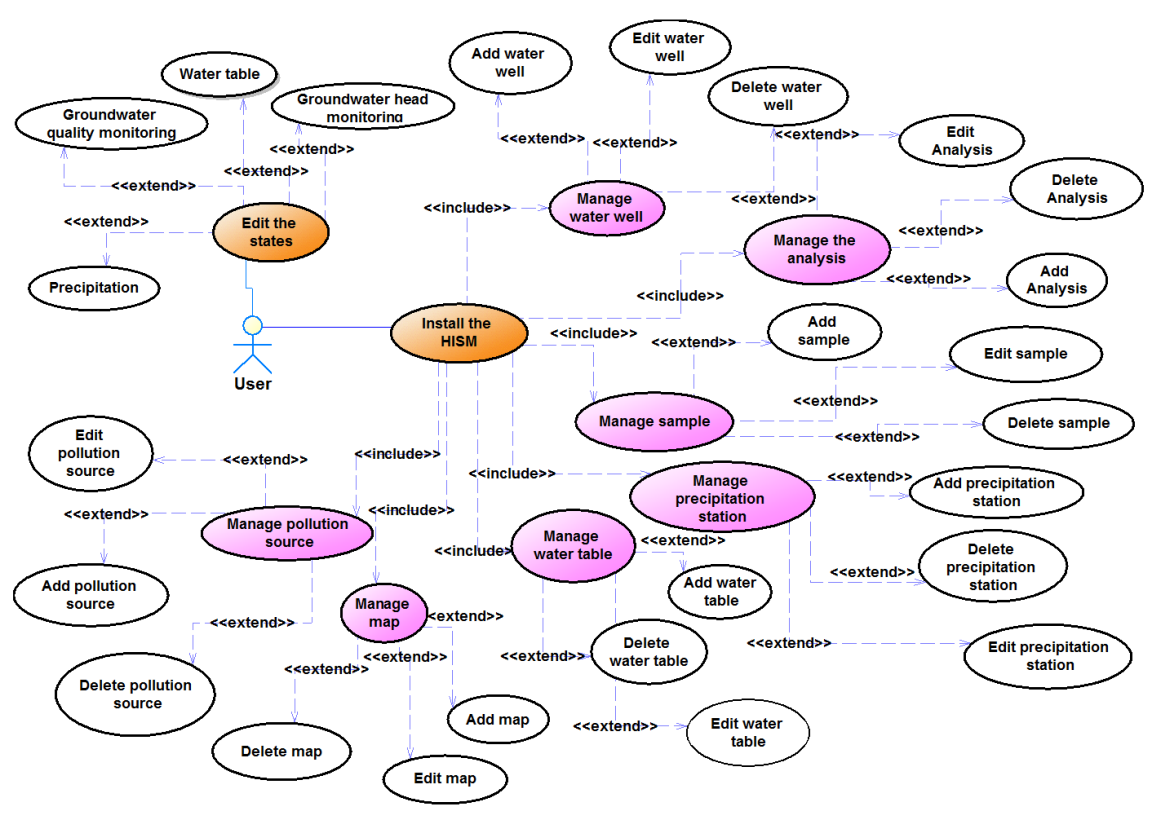

Figure 2. Use-case diagram.

update the selected parameter (add, modify, delete) and edit the reports (Quality monitoring, piezometric monitoring, water tables and Rainfall). The system displays the selected parameter and saves the information.

\subsubsection{Class Diagram}

The class diagram is one of the most widely used diagrams from the UML specification [22] Describing the static view of a system using UML is a process that relies on class diagrams [25].

The class diagram captures details about entities of the system and static relationships between them. Figure 3 describes the structure of the class' diagram of our DSS. In fact, it makes it possible to define the components of the final system. At this phase, every class has a unique name, attributes (label, size, type ...) and all the applicable operations to this class. The data dictionary presents the following classes: Water well, Sample, Analysis type, Analysis, Nature, Lithology, Type of measurement, Rainfall stations, Rainfall, Water table, Historic water table, Map, Governorate, Delegation, Pollution sources and Actors.

\subsubsection{Sequence Diagram}

The sequence diagram describes how processes operate (order and interactions). It also shows object interactions arranged in time sequence. For each task of the system, the sequence diagram designs the objects and classes scenario and the sequence of messages exchanged between the objects. Figure 4 presents the sequence diagram of a shapefile.

\subsection{Data Acquisition (DAQ)}

This descriptive component includes the quantitative and qualitative data of the water wells inventoried by the regional office of agriculture development of 


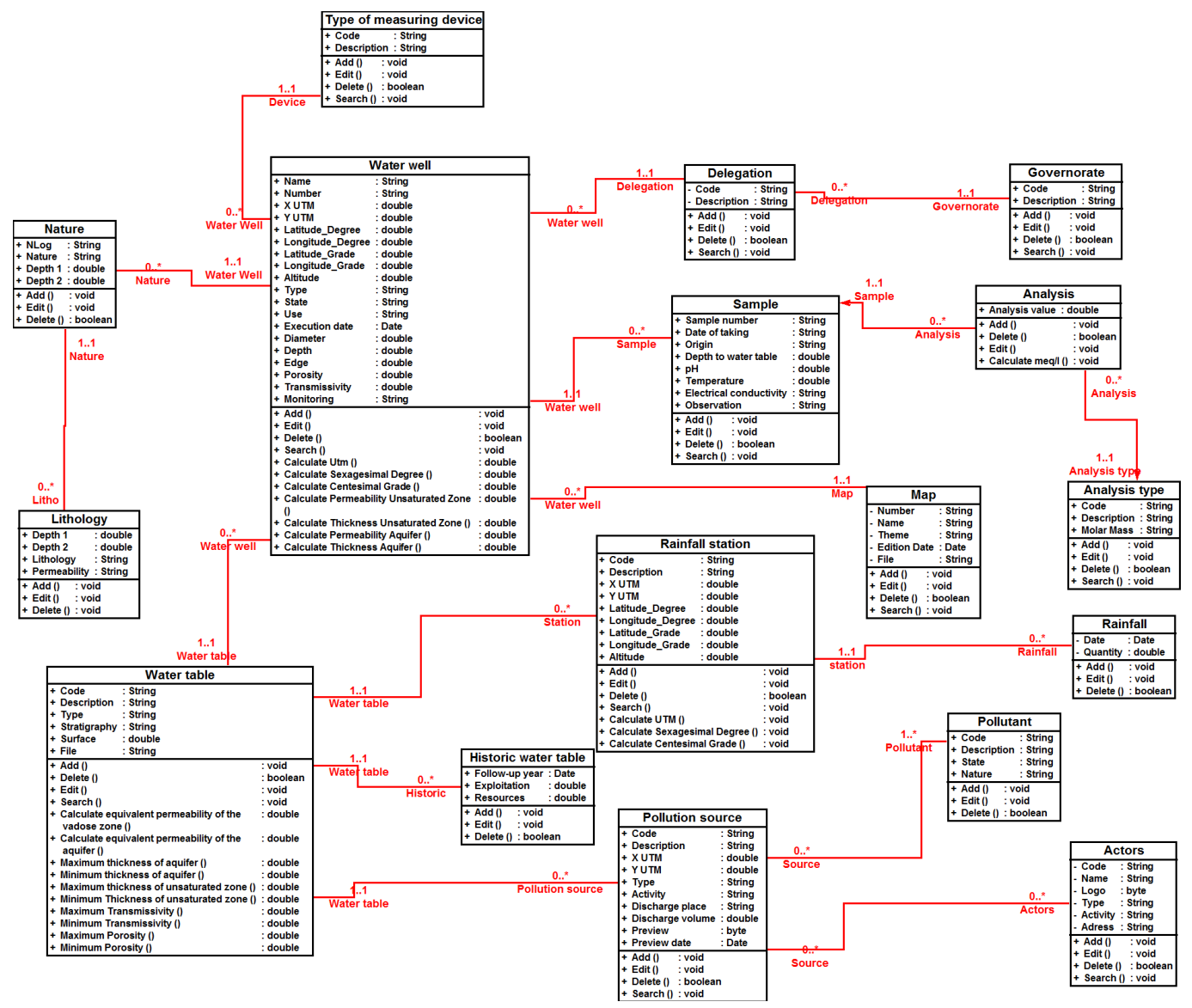

Figure 3. Class diagram.

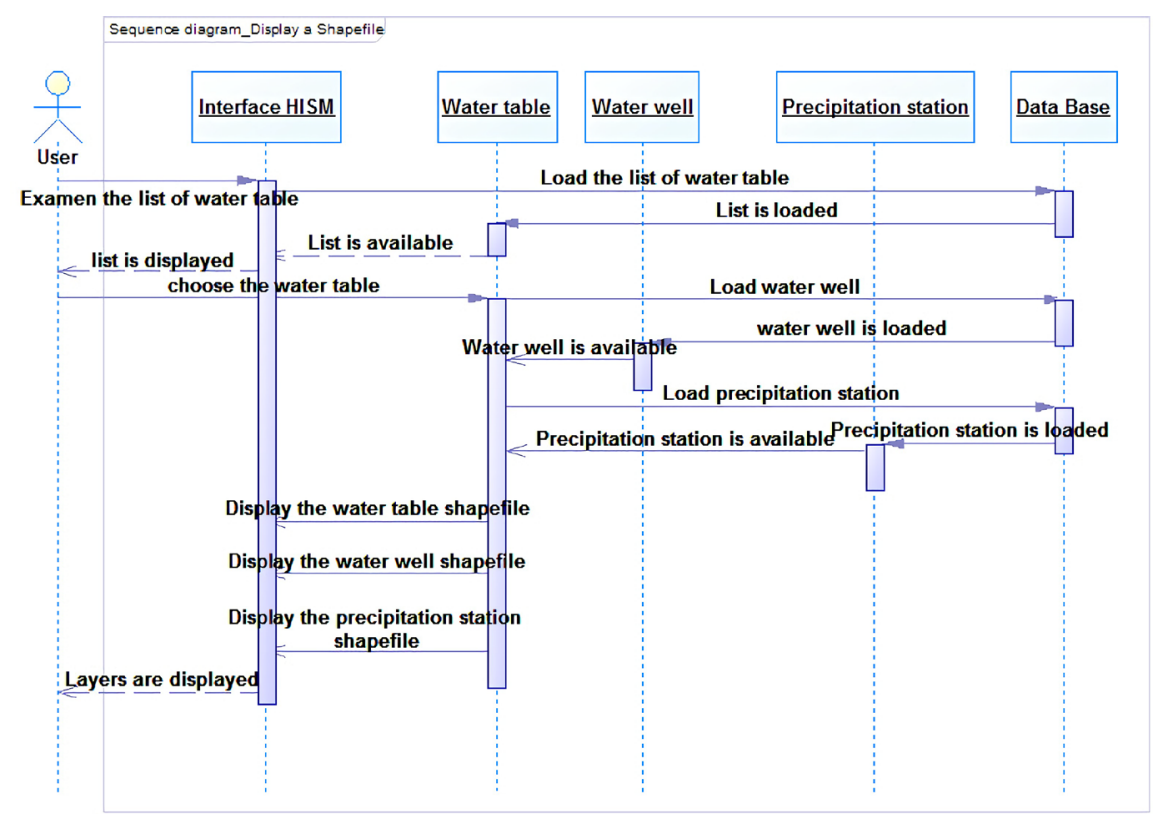

Figure 4. Sequence diagram.

Monastir. It includes the field surveys carried out in this framework as well as the climatic, piezometric, geochemical and the pollution sources data. The spa- 
tial component is a cartographic database that stores data in which the objects are represented by geometric entities (point, arc and polygon) such as pedology, land use, topographic and geological data. Acquisition of these later is based mainly, on three processes: Scanning, georeferencing and digitization of the topographic and geologic maps.

\subsection{Software Implementation and Development}

In order to achieve this process, we propose to use both the object-oriented development approach and the georelational models attached to GIS databases. The DSS is developed in Visual Basic (VB.net) using the Visual Studio Integrated Development Environment (IDE) that implements the geographic information system library "DotSpatial". We had applied the conceptual model in the Database Management System (DBMS). This latter is based on the relational schema which describes the different relationships between the data tables. The georelational model consists of linking a relational database to geometrical features. The modeled entities are organized into categories sharing common characteristics. A table represents each category. The different attributes occur as columns of the table, and the rows assure the data registration. Relationships "one-to-one" or "one-to-many" can be established between tables [33].

The design of semantic data begins firstly with the creation of an SQL database (MS Access) using data entry forms. The Application Menu represents the main menu of the developed application that implements the Windows Ribbon framework (Figure 5). It is formed by three main interfaces namely: "Hydrogeological Information System of Monastir (HISM)", "Reports" and "GIS Data". This latter allows the user to view, add, modify, and delete the data of water well, sample, rainfall, water tables and maps. Figure 6 and Figure 7 describes input form for rainfall records and importing and/or exporting digitized layers respectively. The conversion of water points and rainfall stations from geographic into metric coordinates is executed within the DSS (Figure 8). For each piezometer and water drilling, the stratigraphy and lithology are seized for calculated the equivalent permeability vertical for vadose zone and the equivalent permeability horizontal for aquifer (Figure 9).

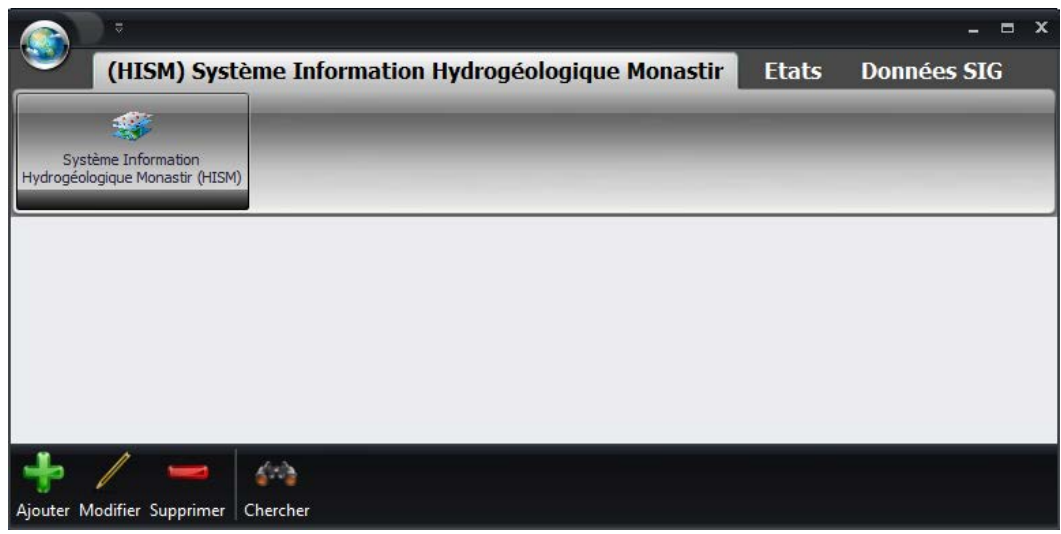

Figure 5. Application principal menu. 


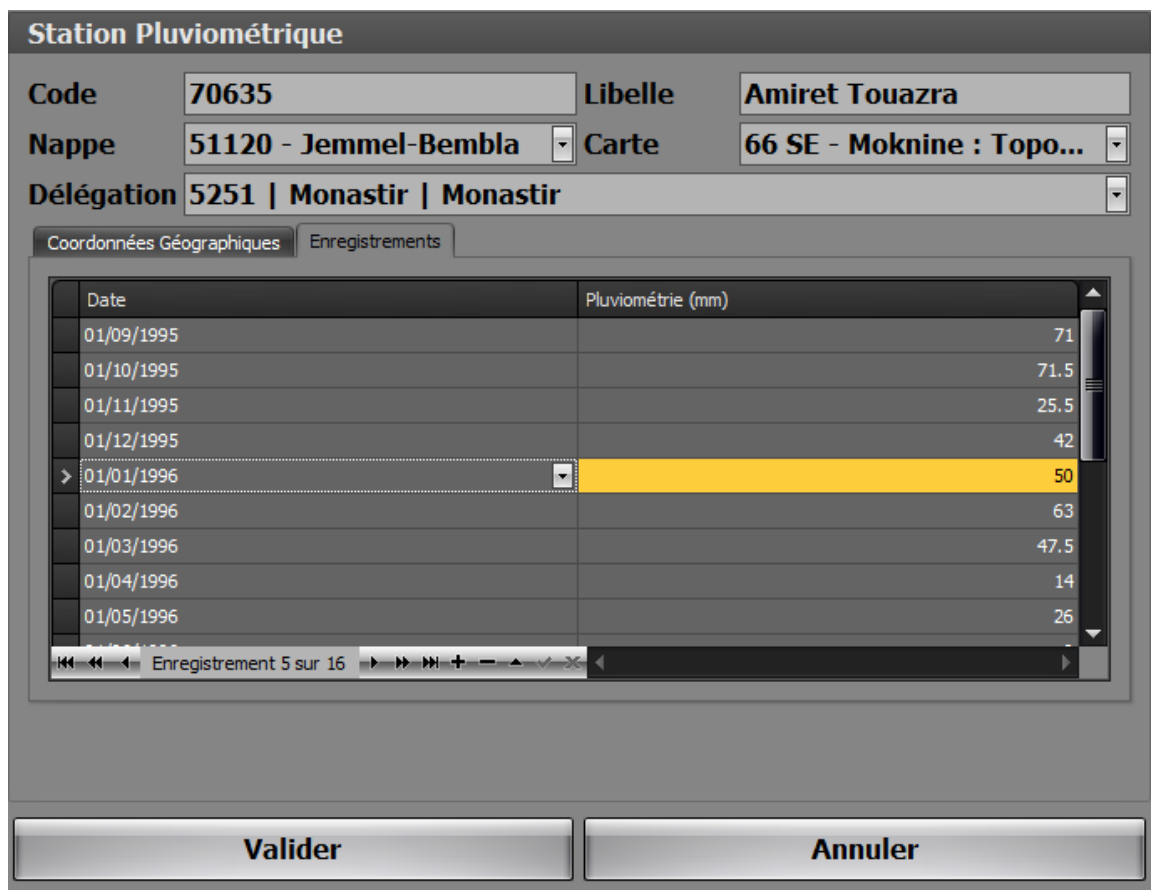

Figure 6. Input form for rainfall records.

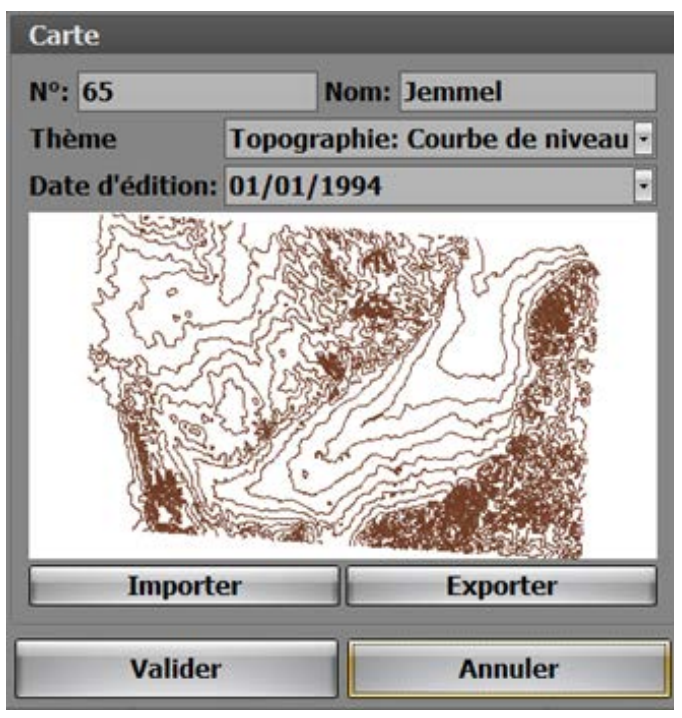

Figure 7. Input form for importing and/or exporting digitized layers.

The "Reports" component grants viewing and updating groundwater level measurement, quality and rainfall over time. Figure 10 shows the report of variation of salinity as a function of time. The interface for the "Water Table" shows water well equivalent permeability of the vadose zone and the aquifer at water drilling with an object identifier "19536/4" (Figure 11).

Figure 12 describes the structure of the dynamic interface of the Hydrogeological Information System (HISM) of Monastir composed of four components. The menu bar enables to add and remove themes, change the layout and print. A toolbar is used to perform spatial analysis such as identification, zoom, move, 


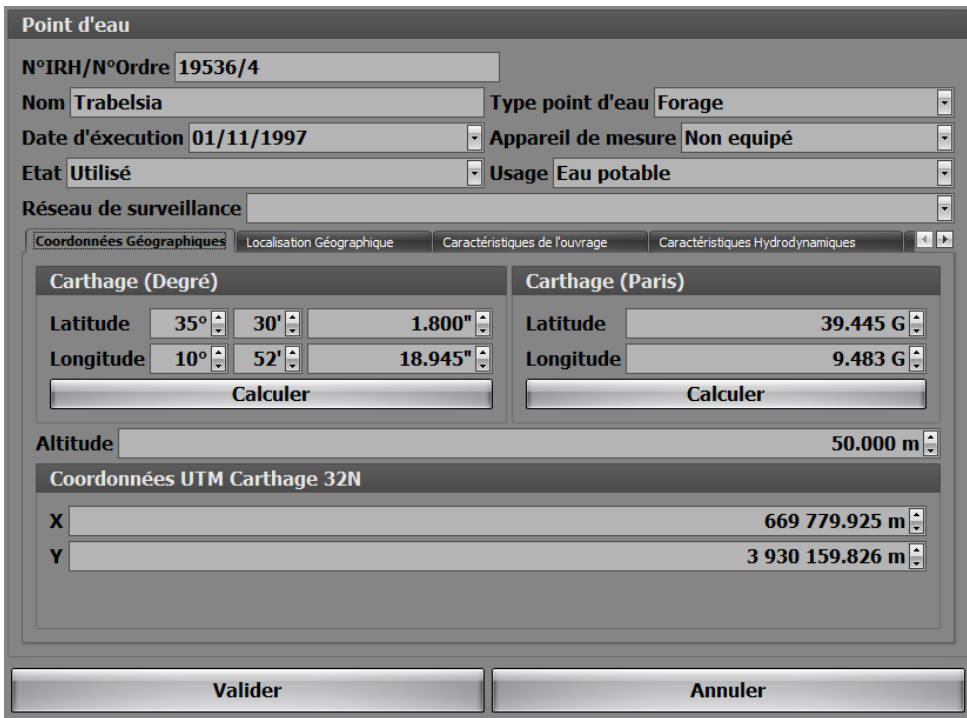

Figure 8. Input form for geographic coordinates.

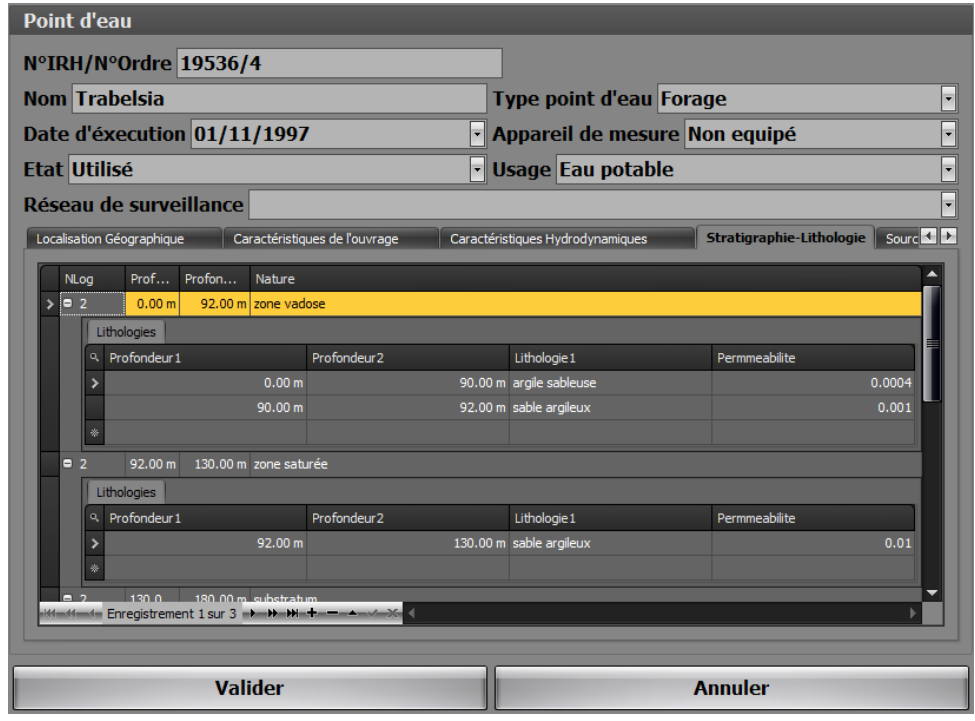

Figure 9. Input form for stratigraphy and lithology at water point.

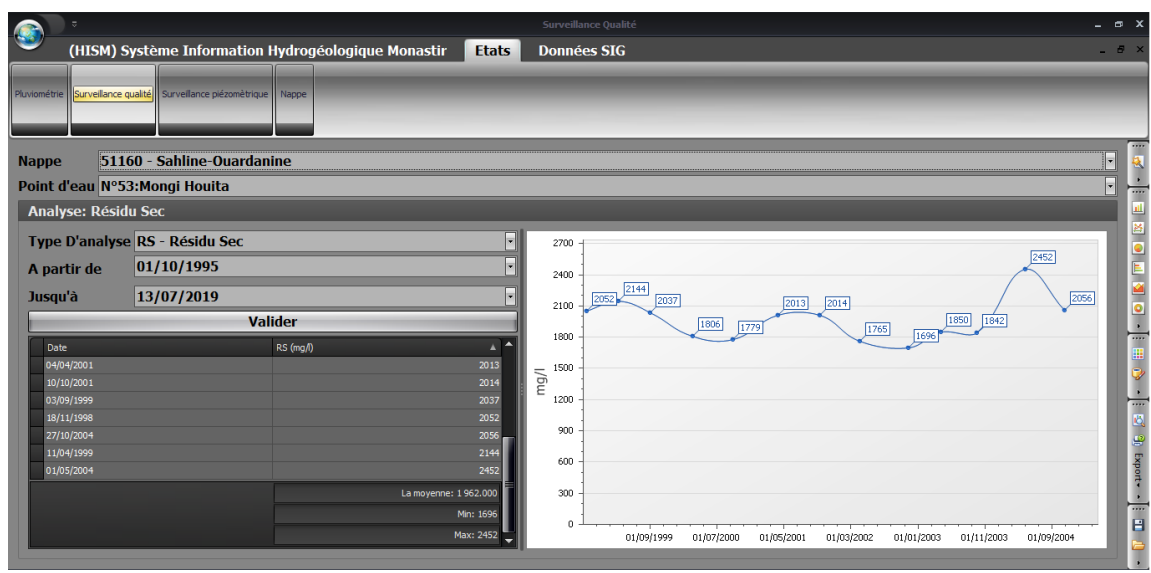

Figure 10. Report of variation of salinity as a function of time. 


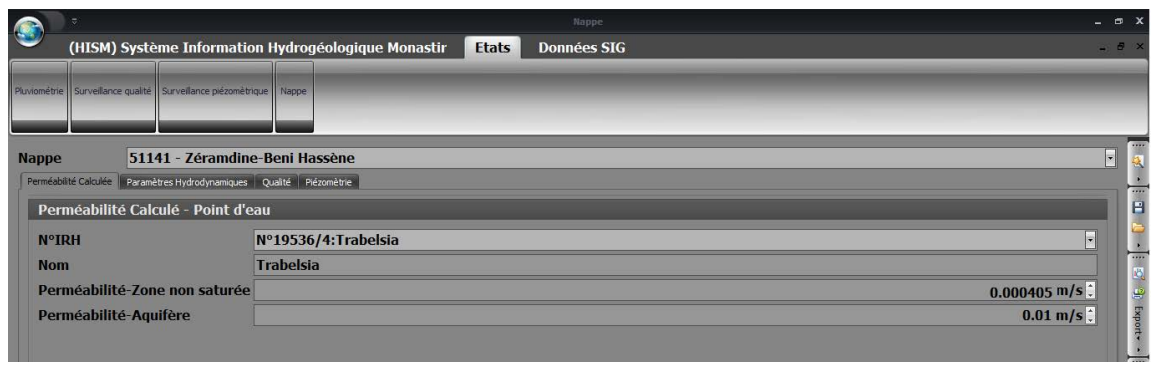

Figure 11. Equivalent permeability of the vadose zone and the aquifer at water point.

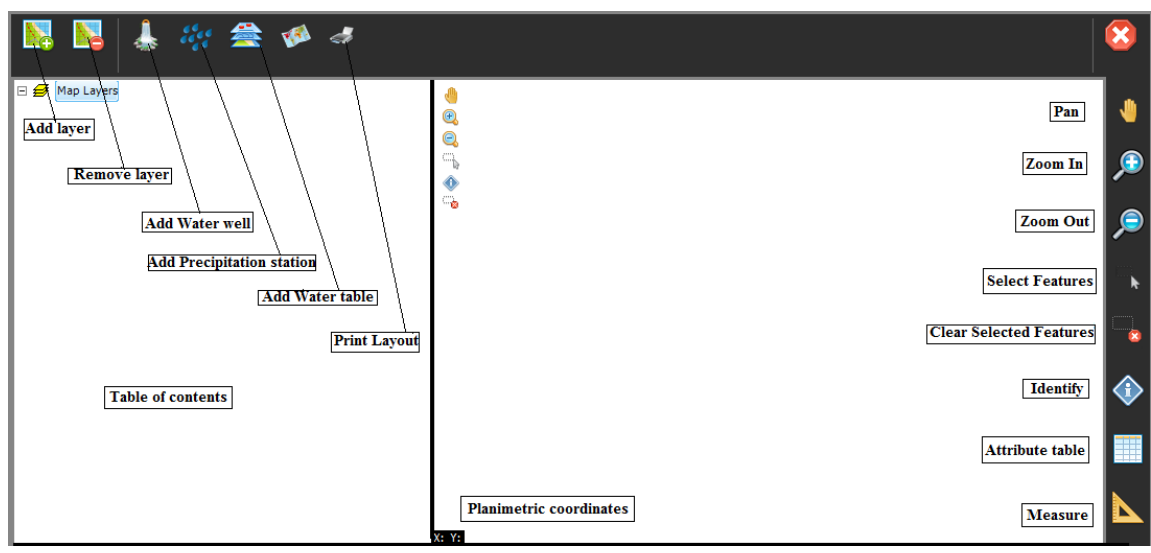

Figure 12. Dynamic interface of the Hydrogeological Information System of Monastir (HISM).

select, remove selection, attribute table and measure distances. The table of contents helps to add the geographic layers, viewing themes area with their planimetric coordinates.

\section{Application of DSS: Case of Moknine Superficial Coastal Aquifer}

Three main distinct applications of HISM are recognized: 1) the management of hydrogeological data, 2) hydrogeological maps elaboration, 3) vulnerability assessment based on overlay and index methods.

This DSS was applied to the superficial coastal aquifer system of Moknine. This region is located in the north-eastern part of Tunisia, between the latitudes 3936 and $3951 \mathrm{~N}$ and the longitudes 663 and $685 \mathrm{E}$ (Figure 13). The Moknine region is influenced by the dry and hot climate from the south and the Mediterranean humid and temperate climate from the north. The annual average temperature is about $19^{\circ} \mathrm{C}$. Rainfall constitutes the main hydrological factor in the region, with an annual average of $350 \mathrm{~mm}$ [34].

\subsection{Hydrodynamic Functioning Model}

The Moknine superficial coastal aquifer system consists of sandy levels, sandstones and calcareous encrustations separated by sandy-clay levels. There is considerable variability in its hydrodynamic characteristics where the Teboulba region 


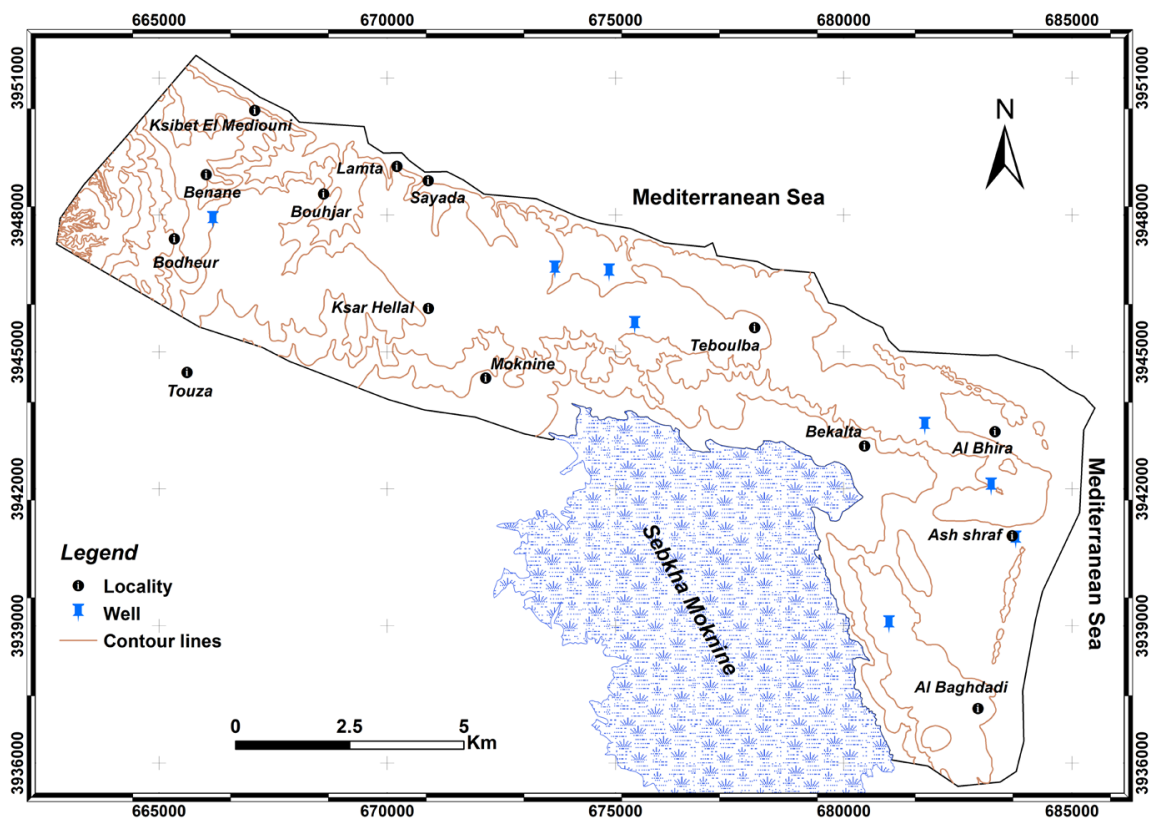

Figure 13. Location of the study area.

has high hydraulic gradients. The mapping of piezometry revealed the existence of perched groundwater within the groundwater system of the Moknine region. At the level of Bekalta, flow is from a piezometric dome to the sebkha on one side and the sea on the other. Monitoring of the piezometry history at the Teboulba region highlighted the impact of artificial recharge and the behavior of perched groundwater within the phreatic system.

The advanced groundwater analysis in the Moknine region has shown that they are mostly brackish. The salty waters characterize the coastal area of Bekalta and the northwest of the sebkha of Moknine. Freshwater was identified (0.6 to 2 $\mathrm{g} / \mathrm{l})$ in the Teboulba area and east of the Moknine sebkha. In the upstream part, and south of Moknine, it is essentially the dissolution/precipitation of minerals that dominate. The mineralization of the waters in the regions of Ksibet elMediouni-Lamta-bouhjar-KsarHellal-Moknine and south of the city of Teboulba results from mixtures, mainly by the contribution of domestic sewage and seawater intrusion. The mixing and ion exchange process are responsible for the mineralization of the waters at the western edge of the Moknine Sebkha. North and east of Bekalta, there is a mix with marine waters.

Figure 14 illustrates Hydrodynamic functioning model of Moknine superficial coastal aquifer system. This model shows three compartments of different characteristics. At the Ksibet ElMediouni-Lamta-Bouhjar-Sayada and Fadhlin-Al Bhira compartments, the reservoir has a reduced thickness and sodium chloride facies. In the north-west, local recharge leads to a dilution of waters where the salinity varies from 1.6 to $3 \mathrm{~g} / \mathrm{l}$. To the east, in the region of Al Fadlin-Al Bhira, salinity is high $(6 \mathrm{~g} / \mathrm{l})$. In the Teboulba region, the model reveals the presence of good quality perched aquifers and reservoir thickening with mixed $\mathrm{Na}-\mathrm{Ca}-\mathrm{Cl}$ and $\mathrm{Na}-\mathrm{HCO}_{3}$ facies. 


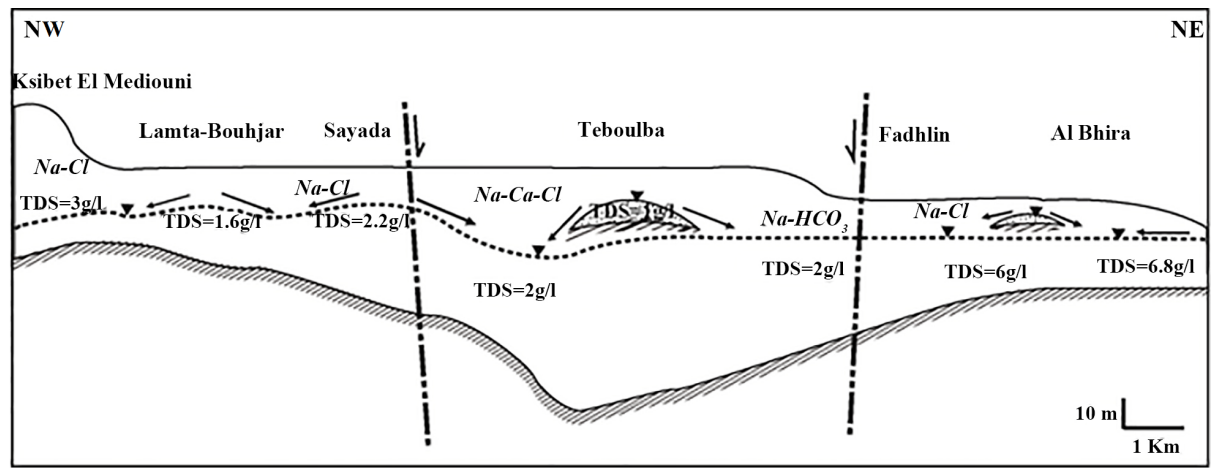

Figure 14. Hydrodynamic functioning model of Moknine superficial coastal aquifer system.

\subsection{Groundwater Vulnerability Mapping}

\subsubsection{GALDIT Method}

The GALDIT indexing method was developed by Chachadi and Lobo-Ferreira (2001) [35] for vulnerability assessment to seawater intrusion. This method uses a set of six parameters influencing the seawater intrusion in the aquifer: Groundwater occurrence, Aquifer hydraulic conductivity, height of groundwater Level above sea level, Distance from the shore, Impact of existing status of seawater intrusion and Thickness of aquifer being mapped. In this model, spatial datasets on depth of groundwater, aquifer thickness, aquifer type, hydrochemical analysis and the aquifer hydraulic conductivity are combined.

The GALDIT model was applied to evaluate the groundwater vulnerability of the Moknine phreatic aquifer system. Calculation of the GALDIT index and can be expressed as follows [36]:

$$
I_{g}=\sum_{i=1}^{6}\left(R_{i} W_{i}\right) / \sum_{i=1}^{6}\left(W_{i}\right)
$$

The subscripts $R_{i}$ and $W_{i}$ denote the rating and the weight for each parameter, respectively.

\subsubsection{Development of Thematic Maps}

The aquifer characteristics of the study area were carried out by examining exploratory data of 9 wells. The aquifer is mainly unconfined and the rating of aquifer type corresponds to 7.5.

The estimate of the aquifer hydraulic conductivity has been made using calculations of equivalent permeability [37]. Based on the reference permeability coefficients assigned for each lithology [38] and the formula given by Castany (1967), the horizontal equivalent permeability is calculated for each piezometer. The hydraulic conductivity was classified into three classes and was rated 7.5 10 (Table 2).

The height of groundwater above mean sea level (L) is calculated from groundwater well measurements during 2005 . The values ranged from $-12 \mathrm{~m}$ to $23 \mathrm{~m}$.

According to the classification of Chachadi and Labo-Ferraira (2001) [25], for the distance from the shore, the rating attributed varies from 2.5 to 10 . 
Table 2. GALDIT parameter weights and ranges for Moknine superficial coastal aquifer system.

\begin{tabular}{|c|c|c|c|c|c|}
\hline & Weight & Rating & & & \\
\hline & & Very low & Low & Medium & High \\
\hline & & 2.5 & 5 & 7.5 & 10 \\
\hline$G$ groundwater occurrence (aquifer type) & 1 & & & $\begin{array}{l}\text { Unconfined } \\
\text { aquifer }\end{array}$ & \\
\hline$A$ aquifer hydraulic conductivity (m/day) & 3 & & & $13-40$ & $40-62$ \\
\hline $\begin{array}{l}L \text { height of groundwater level above sea } \\
\text { level (m) }\end{array}$ & 4 & $2-23$ & $1.5-2$ & $1.5-1$ & $-12-1$ \\
\hline$D$ distance from the shore $(\mathrm{m})$ & 4 & $1000-4000$ & $750-1000$ & $750-500$ & $0-500$ \\
\hline $\begin{array}{l}\text { I impact of existing status of seawater } \\
\text { intrusion }\end{array}$ & 1 & & $1.25-1.5$ & $1.5-2$ & $2-19$ \\
\hline$T$ thickness of aquifer being mapped (m) & 2 & & & & $18-84$ \\
\hline
\end{tabular}

Geochemistry prospecting techniques and hydrogeochimical analysis are required to determine impact of existing status of seawater intrusion which can be computed using the ratio of $(\mathrm{Cl} / \mathrm{HCO}+\mathrm{CO})$. Three classes are recorded for this seawater intrusion indicator (Table 2).

All the parameter layers were then superposed in HISM environment to produce the GALDIT map which identifies areas more likely to be susceptible to seawater intrusion.

GALDIT vulnerability map of the Moknine superficial coastal aquifer (Figure 15) shows three degrees of vulnerability; low, moderate and high with $39.9 \%$, $43.8 \%$ and $16.3 \%$ of the area, respectively. Except for the Lamta-Sayada-Bouhjar region, the coastal zone is the most susceptible and the most exposed to seawater intrusion. This high vulnerability can be explained by the limited distance from the coast and the low piezometric levels.

\section{Conclusions}

The present research emphasizes the importance of developing a Decision Support System (DSS) as a helpful and excellent decision-making tool for groundwater management.

The design and implementation of this DSS called Hydrogeological Information system for Monastir region (HISM) are a new concept based on the Object Oriented approach $(\mathrm{OO})$ whose:

- The modeling language is the Unified Modeling Language (UML);

- The programming language is Visual Basic (VB.net) in an environment of Visual Studio integrated development;

- The "Dotspatial" library is used for the management of geographical information layers;

- The database management system (DBMS) is relational: Microsoft Access.

A relational hydrogeological database coupled to a Hydrogeological Information System (HISM) allows the rapid and efficient processing of large volumes of 


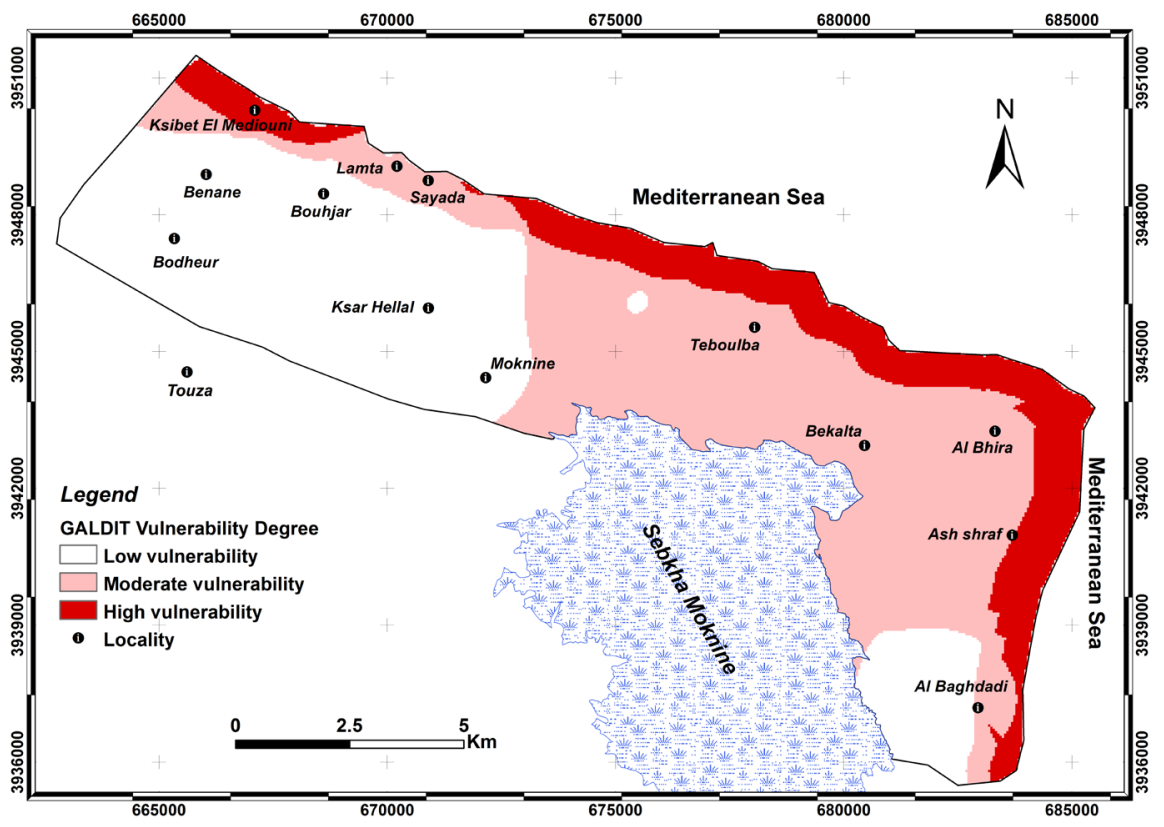

Figure 15. Vulnerability to seawater intrusion degree for Moknine superficial coastal aquifer system.

spatial data from multiple sources. The interactive interface (HISM) is the link between the two components supported by the application. It ensures the visualization of the various geographical layers, the storage and update of the data, the change of scale and the restitution of thematic maps.

Through spatial and attribute requests, the DSS permits the display and analysis of geographic information layers to define the hydrodynamic functioning model of aquifer systems and mapping their vulnerability to seawater intrusion.

Indeed, the compilation and the synthesis of geological, topographical, structural and piezometric data allowed the construction of the hydrodynamic conceptual model of the groundwater system in the study area. It is characterized by a lenticular geometry where permeable levels are inserted in a semi-permeable mass with locally perched hydrogeological entities. The hydrochemical approach enabled the development of thematic maps as well as the origins and processes responsible for groundwater quality. The mineralization of the groundwater system is controlled by the dissolution of evaporating and carbonates minerals, mixing reactions, ion exchange and seawater intrusion. The contribution of marine waters to the groundwater quality is manifested in the northeast of Bekalta where the salinity is greater than $6 \mathrm{~g} / \mathrm{l}$.

The groundwater vulnerability of the Moknine is evaluated using the GALDIT empirical model. This method yields six hydrogeologic parameters, which are Groundwater occurrence, Aquifer hydraulic conductivity, height of groundwater Level above sea level, Distance from the shore, Impact of existing status of seawater intrusion and Thickness of aquifer being mapped. The northeastern part of the study area is the most vulnerable area.

In order to protect the water resource of the study area some recommenda- 
tions can be proposed:

- A systematic inventory along the northern and eastern coastal zone to monitor the spatial and vertical salinity evolution;

- Setting up of a surveillance and warning system in strong vulnerable areas and at high risk of contamination, mainly the Bekalta region.

\section{Conflicts of Interest}

The authors declare no conflicts of interest regarding the publication of this paper.

\section{References}

[1] Profil environmental de la Tunisie (2012) EURONET Consortium. Report.

[2] Gogu, R.C., Carabin, G., Hallet, V., Peters, V. and Dassargues, A. (2001) GIS-Based Hydrogeological Databases and Groundwater Modeling. Hydrogeology Journal, 9, 555-569. https://doi.org/10.1007/s10040-001-0167-3

[3] Foucher, S. (2000) Elaboration d'un système d'Information Géographique: Application au système hydrologique de la vallée du Rio Zongo (Bolivie). Rapport de stage. Institut de recherche pour le développement. Université Montpellier II-CNAM. 33 p.

[4] Rayed, C.A. (2012) Using GIS for Modeling a Spatial DSS for Industrial Pollution in Egypt. American Journal of Geographic Information System, 1, 100-104. https://doi.org/10.5923/j.ajgis.20120104.01

[5] Alharbi, R. (2015) A GIS-Based Decision Support System for Reducing Air Ambulance Response Times: A Case Study on Public Schools in Jeddah City. Journal of Geographic Information System, 7, 384-391. https://doi.org/10.4236/jgis.2015.74030

[6] Li, Y.P., Huang, G.H. and Nie, S.L. (2006) An Interval-Parameter Multi-Stage Stochastic Programming Model for Water Resources Management under Uncertainty. Advances in Water Resources, 29, 776-789. https://doi.org/10.1016/j.advwatres.2005.07.008

[7] Chen, Y.M. (1997) Management of Water Resources Using Improved Genetic Algorithms. Computers and Electronics in Agriculture, 18, 117-127. https://doi.org/10.1016/S0168-1699(97)00024-0

[8] Ge, Y., Li, X., Huang, C. and Nan, Z. (2013) A Decision Support System for Irrigation Water Allocation along the Middle Reaches of the Heihe River Basin, Northwest China. Environmental Modelling \& Software, 47, 182-192. https://doi.org/10.1016/j.envsoft.2013.05.010

[9] Assaf, H. and Saadeh, M. (2008) Assessing Water Quality Management Options in the Upper Litani Basin, Lebanon, Using an Integrated GIS-Based Decision Support System. Environmental Modelling \& Software, 23, 1327-1337. https://doi.org/10.1016/j.envsoft.2008.03.006

[10] Xiang, S. and Zhou, W. (2009) Development of Groundwater Resources Management System Based on GIS in Poyang Lake Catchment. International Conference on Environmental Science and Information Application Technology, Wuhan, 4-5 July 2009, 410-413. https://doi.org/10.1109/ESIAT.2009.108

[11] Guo, L., Xiao, L., Tang, X. and Hu, Z. (2010) Application of GIS and Remote Sensing Techniques for Water Resources Management. The 2 nd Conference on Environmental Science and Information Application Technology, Wuhan, 17-18 July 
2010, 738-741. https://doi.org/10.1109/ESIAT.2010.5568931

[12] Mathiyalagan, V., Grunwald, S., Reddy, K.R. and Bloom, S.A. (2005) A Web-GIS and Geodatabase for Florida's Wetlands. Computers and Electronics in Agriculture, 47, 69-75. https://doi.org/10.1016/j.compag.2004.08.003

[13] Konan Waidhet, A.B., Kouadio, K.E., Dibi, B., Savane, I. and Lazar, G. (2013) Contribution of a GIS to the Management of Rice Project in the North-West of Côte d'Ivoire: The Case of Denguele Region. International Journal of Innovation and Applied Studies, 2, 436-444.

[14] Khemiri, S., Mansouri, S., Khnissi, A. and Zargouni, F. (2013) Implementation of GIS and Geographic RDBMS Prototype for Water Resources Management. Zeuss-Koutine Basin (South of Tunisia). Journal of Geographic Information System, 5, 429-445. https://doi.org/10.4236/jgis.2013.55041

[15] Riahi, I., Bouaziz, S. and Ben Dhia, H. (2015) Problèmes d'intégration de données hydrogéologiques dans un Système d'Information Géographique dédié à la gestion intégrée de ressources en eau souterraine. Journal of Scientific Association for Water Information Systems, 1, 40-45.

[16] Srivastava, S.K. (2013) Threshold Concepts in Geographical Information Systems: A Step towards Conceptual Understanding. Journal of Geography in Higher Education, 37, 367-384. https://doi.org/10.1080/03098265.2013.775569

[17] Goodchild, M.F. (1996) The Application of Advanced Information Technology in Assessing Environmental Impacts. In: Corwin, D.L. and Loague, K., Eds., Applications of GIS to the Modelling of Non-Point Source of Pollutants in the Vadose Zone, SSSA Special Publication 48, Soil Science Society of America, Inc., Madison, $1-17$.

[18] Huang, G.H., Liu, L., Chakma, A., Wu, S.M., Wang, X.H. and Yin, Y.Y. (1999) A Hybrid GIS-Supported Watershed Modeling System: Application to the Lake Erhai Basin, China. Hydrological Sciences Journal, 44, 597-610. https://doi.org/10.1080/02626669909492255

[19] Heuvelink, G.B.M. (1998) Error Propagation in Environmental Modelling with GIS. Taylor and Francis, London.

[20] Criollo, R., Velasco, V., Nardi, A., Vries, L.M., Riera, C., Scheiber, L., Jurado, A., Brouyere, S., Pujades, E., Rossetto, R. and Sune, E.V. (2019) AkvaGIS: An Open Source Tool for Water Quantity and Quality Management. Computers and Geosciences, 127, 123-132. https://doi.org/10.1016/j.cageo.2018.10.012

[21] Çubuk, U. (2004) Analysis Pattern of Anliurfa Harran Plain in UML and Its Implementation in Geodatabase. Thesis Submitted to the Graduate School of Natural and Applied Sciences of the Middle East Technical University, 137 p.

[22] Booch, G., Rumbaugh, J. and Jacobson, I. (1999) The Unified Modeling Language User Guide. Addison-Wesley Publishing, Boston.

[23] Booch, G. (1994) Object-Oriented Analysis and Design with Applications. 2nd Edition, Addison-Wesley Publishing, Boston.

[24] Yourdon, E. (1994) Object-Oriented Systems Design: An Integrated Approach. Prentice-Hall, Englewood Cliffs.

[25] Buliung, R.N. and Kanaroglou, P.S. (2004) On Design and Implementation of an Object-Relational Spatial Database for Activity/Travel Behavior Research. Journal of Geographical Systems, 6, 237-262. https://doi.org/10.1007/s10109-004-0139-y

[26] Rumbaugh, J., Jacobson, I. and Booch, G. (1999) The Unified Modeling Language Reference Manual. Addison-Wesley, Boston. 
[27] Quatrani, T. (2003) Introduction to the Unified Modeling Language. http://www-106.ibm.com/developerworks/rational/library/998.html

[28] Rossetto, R., Baldi, B., Perna, M. and Carmignani, L. (2007) Use of GIS Hydrogeological Database for Integrated Water Management. Geophysical Research $A b$ stracts, 9, Article ID: 09294.

[29] Taylor, D.A. (1998) Object Technology: A Manager's Guide. 2nd Edition, Addison-Wesley Longman, Boston.

[30] Hentati, I. (2016) Gestion et vulnérabilité à la pollution des aquifères de la région de Monastir par un Système d'Information Hydrogéologique. Thèse de doctorat, Université de Sfax, Tunisie.

[31] Rabia, M.C. (1998) Systèmes d'Informations Géo-Scientifiques et Télédétection multi-capteurs: Application à une étude multi-thèmes de la Jeffara orientale. Thèse de doctorat Géologie. Fac. Sc. Tunis, Tunisie.

[32] Xie, W., Zhang, H. and Gao, G. (2011) Design of a Hydrologic Observation Database System. In: Lin, S. and Huang, X., Eds., Advances in Computer Science, Environment, Ecoinformatics, and Education, Communications in Computer and Information Science, Vol. 216, Springer, Berlin, Heidelberg, 124-128. https://doi.org/10.1007/978-3-642-23345-6 24

[33] Levene, M. and Loizou, G. (1999) A Guided Tour of Relational Databases and Beyond. Springer, Berlin, Heidelberg, New York.

https://doi.org/10.1007/978-0-85729-349-7

[34] Hentati, I., Triki, I., Trabelsi, N. and Zairi, M. (2016) Piezometry Mapping Accuracy Based on Elevation Extracted from Various Spatial Data Sources. Environmental Earth Sciences, 75, 802. https://doi.org/10.1007/s12665-016-5589-2

[35] Chachadi, A.G. and Lobo-Ferreira, J.P. (2001) Sea Water Intrusion Vulnerability Mapping of Aquifers Using GALDIT Method. In: Proceedings of Workshop on Modeling in Hydrogeology, Anna University, Chennai, 143-156.

[36] Chachadi, A.G. and Ferreira, J.P.L. (2005) Assessing Aquifer Vulnerability to Sea-Water Intrusion Using GALDIT Method: Part 2 GALDIT Indicators Description. 4th Inter-Celtic Colloquium on Hydrology and Management of Water Resources, Guimaraes, 11-14 July 2005, 1-12.

[37] Hentati, I., Zairi, M. and Ben Dhia, H. (2011) A Statistical and Geographical Information System Analysis for Groundwater Intrinsic Vulnerability: A Validated Case Study from Sfax-Agareb, Tunisia. Water and Environment Journal, 25, 400-411. https://doi.org/10.1111/j.1747-6593.2010.00235.x

[38] Castany, G. (1967) Traité Pratique des eaux Souterraines. 2nd Edition, Dunod, Paris, $657 \mathrm{p}$. 